\title{
Foreword: Christy and France
}

\section{Anne Williams}

\section{(2) OpenEdition \\ Journals}

Electronic version

URL: http://journals.openedition.org/shakespeare/4935

DOI: 10.4000/shakespeare.4935

ISSN: 2271-6424

\section{Publisher}

Société Française Shakespeare

\section{Electronic reference}

Anne Williams, "Foreword: Christy and France », Actes des congrès de la Société française Shakespeare [Online], 37 | 2019, Online since 14 June 2019, connection on 16 June 2019. URL : http:// journals.openedition.org/shakespeare/4935; DOI : 10.4000/shakespeare.4935

This text was automatically generated on 16 June 2019.

(C) SFS 


\title{
Foreword: Christy and France
}

\author{
Anne Williams
}

1 In 2000 Christy Desmet's doctors sent her to the University of Nebraska Hospital for a Tcell transplant to treat a rare form of lymphoma. (She had survived Hodgkin's a decade earlier.) It was a stringent cure requiring a lot of powerful drugs. After a perfectly lucid phone conversation, Christy asked, “Am I in France?" She didn't remember the conversation afterwards, but always thought it was both funny and appropriate that her delirious fantasies took her to Paris.

2 The treatment worked and for seventeen years afterward, Christy taught, wrote, and travelled extensively, often to France. After my husband died, I started accompanying her to Shakespearean conferences, which tended to meet in the most glamourous places. The first we attended was in Paris commemorating the four-hundredth anniversary of Shakespeare's death. The following year - and we had no scholarly excuses this time we spent a week in Paris and one in Provence. Then we became regulars at the Sociéte Française Shakespeare (SFS). January is perhaps not the ideal time to visit Paris, but we didn't care. We would arrive on Sunday morning before the conference began, check into our hotel, and then go to hear the magnificent organ at St. Sulpice. Inveterate tourists, we filled our free time with museums, operas, and "research" in highly-regarded pâtisseries. We went to the opera at the Palais Garnier and the Bastille, and had some wonderful dinners at small restaurants near our hotel in the $7^{\text {th }}$ arrondissement, which was beginning to feel like our own quartier.

3 One of the pleasures of the SFS was that since it was relatively small, we could look forward to seeing colleagues repeatedly, and hear every paper. We also attended a performance of Richard III I shall never forget, and the next day were privileged to hear its director speak about the choices he made in staging this monstrous history. We also ventured out to the Théâtre des Quartiers d'lvry to see an experimental play about the four queens associated with Richard III. Our taxi driver got lost, but we got there in time to see the opening scene where the queens appear on roller skates - a directorial choice that we never entirely figured out. And after another conference was over we rather bravely rented a car and drove to Berry, visiting Bourges and its lovely cathedral and 
Nohant, home of George Sand. We were guided by the GPS we called "Madame," who misguided us only once - at rush hour as we returned to Paris.

4 In 2016 and 2017 Christy and her colleague at Georgia, Sujata Iyengar, were arranging an exchange program with the University of Montpellier. She wrote enthusiastically about the beauties of his city and its remarkable history. As she wrote to David, her husband: "We saw where Rabelais lived when a student ... the med school in Montpellier, the oldest one in Europe in continuous existence. They apparently welcomed Jewish and Muslim medical scholars fleeing Spain and so had a star-quality faculty. Chocolates and gelato followed."

Christy died far too young, but the treatments that gave her so many years had damaged her heart irreparably. I suspect that far more than most of us she knew that life is short, and so she filled those years with such brilliant scholarship and such enthusiasm for friends, colleagues, students, work, and travel. Indeed, elle a cueilli les roses de la vie.

\section{AUTHOR}

ANNE WILLIAMS

University of Georgia 